\section{（6）鶏病予防対策の強化について}

最近に和ける鷄の各種伝染性疾病の多発は,ひなの育 成率の低下など養舀産業に大きな影響を及ぼしているこ とにかんがみ，「鶏病予防詨策の強化について」昭和 45 年 2 月 5 日付け 44 畜A第 5979 号畜産局長通遧）が通 達され，さらに，こ机が実施上の注意について畜産局衛 生課長から通知され, 昭和 45 年度からこれら一連の予 防事業が推進されたが，本年度においても，本事業を維 続実施する。

鷄病予防対策は, 従来から自衛防疫を基調として推進 しており，いったえ発生のあった場合は，周辺地域への まえ延を防止するために，家音伝染病予防事業により措
置してきたのであるが，最近に和ける舀病多発の原因 が，盖㗖従事者の家畜衛生知識の不足と技術の欠如和よ び環境の污染, とりわけ, 種鷄場と種鵎の污染ならびに これらの種䳕場と種鵎の清浄化につとめるとともに種鷄 用ひなの清浄環境下に蚂方すうを実施して清浄種舀 を育成し，健康ひなの流通をはかることを目的としたる のである、このため, 自衛防疫の推進強化により, 養鵎 農家段階に括汗る環境衛生の向上をすすめる一方, 畜産 局長通達にもとつく鷄病予防対策の強化を維続して併行 させる必要が西るので, 他の鷄病詨策事業との調和をは かりながら，それぞれの事業間に打汗る補完を策して実 施することとする.

\title{
技術 講座
}

\section{豚の衛生 (16)}

\section{農林省家音衛生試験場}

\section{5 豚のトキソプラズマ病*}

この病気以原虫 (Toxoplasma gondii) の感染によって起 こる感染病である。この原虫の分布は世界的で宿主域も また非常に広く，核とんどすべての哺乳類，多数の鳥類 扣よび一部の瓜虫類に沶よんでいる。この特性が本病を して人獣共通の感染病たらしめる理由である。

わが国に掠いて，家畜ではとくに㟲に本病が多く，豚 コレラようの症状を現わし子豚に烼いては死亡するもの が多く，死をま妨机たものは発育不良（ひ派）にな り，相当の経済的な損害をこうむっている。

トキソプラズマはその分類学的な位置がまだ決定され ていない，その生活環はきわわて単純であり，増殖型と シスト型に分けられてきた. しかし，最近トキンプラ ズマを猫に経口感染させるとコクシジウムのように腸の 上皮細胞内飞無性生殖扝よび有性生殖が，また粪便中に オーシストが認められ，このオーシストは形態学的に犬 猫に寄生するコクシジウムの一種であるIsospora bigemina のそれと非常に良く似ていることが認めら机た，猫以外 の哺乳動物や鳥類では無性生殖だけが認められ，有性生 殖は認められていない, 従って猫はトキソプラズマの終 末宿主であり，他の哺乳動物抏よび鳥類は中間宿主と考 えられる，豚にトキソプラズマが感染した場合，無性生 殖の増殖型およびシスト型（震子型）が認められる.

增殖型の虫体は急性期および悪急性期の初期にみら れ，形は三日月型をしており，一端は尖鋭であり，他の 一端は鈍円をなす. 長さ $4 \sim 7 u$, 幅 $2 \sim 4 \mu$ の大きさで

\footnotetext{
* Toxoplasmosis
}

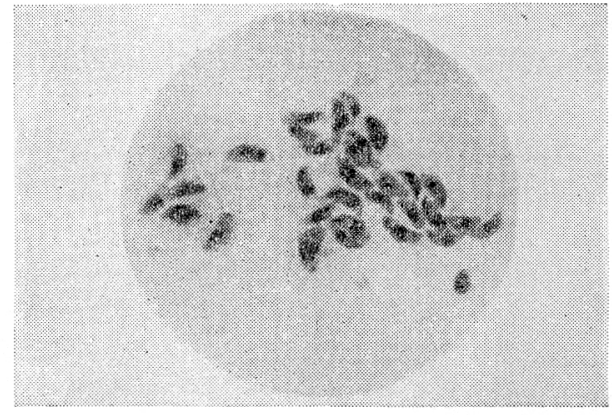

写真 9 增殖型虫体（ギムザ染色）

鞭毛，波状膜のような運動器官はない。ギムザ染色を行 ならと原形質は淡青色に，核は赤紫色に染まる。

トキソプラズマ原虫は偏性細胞奇生性で, 細胞内に浸 入した原虫は2 分裂, または母虫内に 2 個の娘虫が出芽 的に生じる内部出芽によって增殖する。

増殖型虫体禹物体外や死体のなかではす久やかに死 隇し, また乾燥や渗透压の変化, 加熱( $55^{\circ} \mathrm{C} 5$ 分以上), 凍結, 消毒薬和よび人工胃液の作用によって簡単に破壞 されるので, 創傷感染や経粘膜感染は成立するが，経口 感染は成立しにくい。

シスト型は増殖力の弱い株に感染したときや強毒株感 染に执いても增殖に不利な環境, たとえば宿主に免疫が 生じた時とか，あるいは組織培盖において培盖条件が悪 くなった時などに形成する、これはトキソプラズマの集 団が弾力のある膜にかこまれ，球状沈なる。 シスト内の トキソプラズマはゆるやかな速度で分裂し，しだいに数 


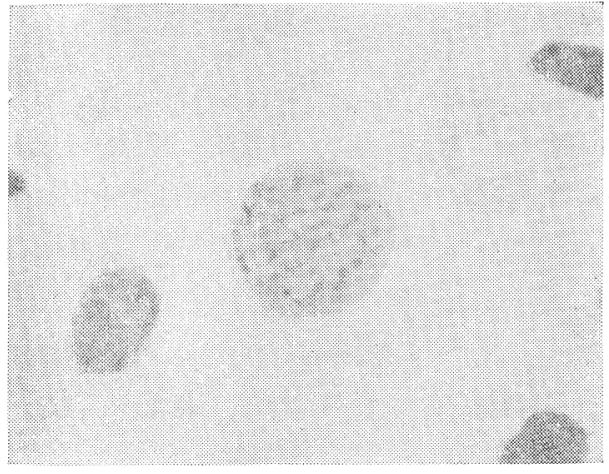

写真10 シスト（ギムザ染色）

を増し，数力月後には直径 $70 \mu$ から $100 \mu$ 飞与達与る ことがある。シスト内の原虫法増殖型の原虫に比し，非 常に多量のグリコーゲンを内蔵しているので, PAS 染 色を行なうと增殖型虫体はほとんど赤染しないがシスト は強く赤染する。

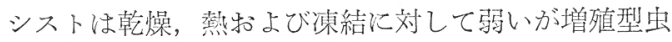
体と異なる点は死体の組織内では冷蔵温度 $\left(4 \sim 5^{\circ} \mathrm{C}\right)$ で 1 力月以上も感染力を失わず，人工胃液に上る消化注対 して 2 時間は感染力灻失わないことで岁る。乙たがって 経口感染も成立与る。

\subsection{1 症 状}

トキソプラズマに感染した大多数の宿主は不顕性感染 に終姢するが，一部には致死的経過をたどるものもあ り, 軽重さまざまの臨床症状学現わす。実際化発病する ものは子豚化多く，子豚では死亡するものが多い，中豚 の発症例もしばしばみられるが, 他の病原体との混合感 染がない限り死亡するるのは少なく、しだいに回復す る. 成豚性子豚に比し, 抗体調査で高い陽性率を示すに

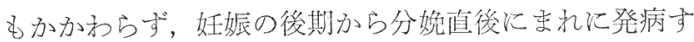
るるのがみられる程度で岗る，全身感染を基盤として带 型的な急性の症状を現わした病豚に招いてはその経過に よって急性期, 悪急性期, 慢性期の 3 期とわけることが できる。

i 、急性期：宿主に侵入した原虫は局所で增殖し，血 行性注全身の藏器にばら变かれ, さかんに分裂增殖して

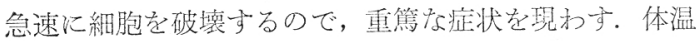
$40 \sim 42^{\circ} \mathrm{C}$ の高熱が続き, 食欲減退, 元氛なく, 水を欲し がる。水様の鼻汁を流し, 鼻鏡が乾燥し, 污染する。呼 吸頻数, 湿性の咳をし, 下疮または便秘する。眼は結 膜が充血し，眼賦を付着する。極期になると食欲廃絶, 起立不能, 横臥し, 呼吸困䧼, 耳翼, 鼻端, 下肢, 下腹 部, 頸部, 背替部にチアノーゼ㐫るいは皮下の漏出性出 血をきたす。重症のものはこの時期体温が急に下降し て死亡する。

ii. 亜急性期 : 発病後 10 14 日ごろから宿主注抗体
が産生され臟器内の原虫は增殖阻止または破壊されるの でしだいに回復する。体温は分利し，食欲も平常にもど るが発育が和く机「七亦豚」になる傾向がある。李た急 性期作られた病変が修復するのに多少の日数を要する ので, 依然, 強い咳などの呼吸器症状がのこる。しか し, 抗体量の少ない脳, 眼抒よび筋肉などでは原虫が破 壤されずに，かなり長い間生存するので，一部の原虫は しだいにンストを形成し始好る。虫体数や寄生部位によ ってはてえかえ様のけいれんや運動障害, 斜頸などの脳 症状や，脈絡網膜炎飞上る失明などの眼症状が認められ ることが岁る。

iii. 慢性期：增殖型の虫体は活とえど消失し、シスト のみが中枢神経系の組織它筋肉内潜在し，「七ネ豚」 汇なるものもあるが，外見上なんら異常索認めないるの が多い。

\subsection{2 診断法}

\subsubsection{1 病原学的診断法}

本病の最も確実な診断法は病豚の梌査材料から塗抹標 本怙よびマウスへの接種によってトキソプラズマを検出 することで岁る。

i 、塗抹標本による検査法 : 急性の症状を现わして死 亡をなは殺した豚の臟器(肺, 朋, 脾, 腎, 膵), リンパ 節（とく飞胃門，肝門，肺門，腸間膜）などの割面から 塗抹標本を作り，メタノール固定，ギムザ染色を施し 450 倍以上の倍率で鏡検して增殖型原虫を検出する。最 近，篮光抗体法を応用与ることにより，雓抹標本中の原 虫を特異的に，乙か子容易に検出することがでさるよう になった。乙かて, 急性期の豚の材料でも, 生前飞抗原 虫剂（ピリメサミン、サルファ剤など）を使用した場合 には，塗怵標本によって原虫を確認することが困難にな

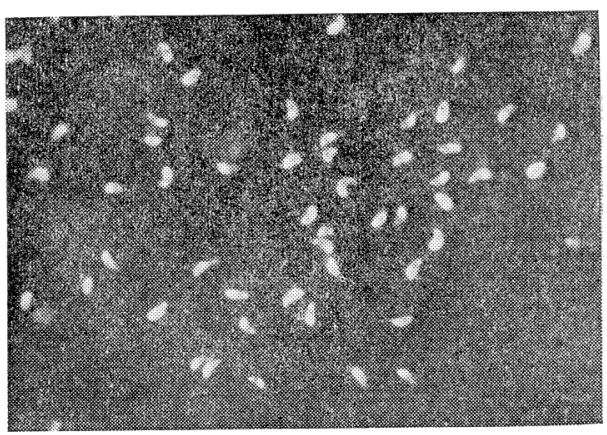

写真11 䍃光抗体によって染色した增殖型虫体 るので,つぎにのベる原虫の分離法を応用しなけ机ばな らない。

ii. 原虫の分離法：この方法虫急性期のもので抗原虫 剂を投与したとか, 亜急性期敊よび慢性期の症例のよら 飞, 塗抹標本から原虫の検出が困難な場合に応用され 
る. 接種材料として脳, 心筋などを選ぶと比較的高率に 原虫を分離することができる。まず材料をあらかじめ鋏 で細切したのち, カップの周囲に氷を入れて泠しなが ら,ホモブレンダーに約 3 分間かけるか, または乳鉢で よく磨砕し, 滅菌生理食塩液で $5 \sim 10$ 倍の乳郕を作り, 滅菌ガーゼでろ過した後 $2,000 \mathrm{rpm} 15$ 分間遠沈し, そ の沈渣に所要量の食塩液を加えて再浮遊したものにペニ シリン，ストレプトマイシンを加えて 1 匹あて0.5〜1.0 $\mathrm{ml}$ を 5 10 匹のマウスの腹腔内に接種する. マウスは 接種後 4 6 週間観察する. 観察期間中に接種マウスが 発病末たは死亡した場合には, それらの腹腔液を $1 / 4$ の 注射針をつけたツベルクリン用の注射器で採取しスライ ドグラスに 1 滴たらし，その上にカバーグラスをのせて 400６00 倍で鏡検する．增殖型の原虫が確認でき机ば 接種材料中に原虫が含んでいたことになる.しかし，接 種マウスが観察期間中に発病しない場合にはマウスを軽 くェーテル麻酔し, 腋下動脈を切って採血し, 血清を分 離して, 色素試験（後述する）用に $-20^{\circ} \mathrm{C}$ 亿保存して和 く、またいっぽう，脳を採取して 2 分し，その一部をス ライドグラスに取り, 少量の生理食塩液を加えてカバー グラスでこれを拈扒い，強く圧して弱拡大（100 倍）で 鏡検してシストの有無を検査する. 鏡検によってシスト が検出できない場合には脳の他の一部を 10 倍乳剂にし て、つぎの新鮮マウスにさきにのべた方法にしたがって 注射し,さらに原虫の検出につとめる. また接種マウス 加ら採取して打いた血清について色素試験を行ない，16 倍以上の力価を示すマウスの脳から高率にシストを確認 することができる. 色素試験㓌性のものは接種材料中に 原虫が含んでいないるのとして 2 代目でマウス継代を中 止する.

以上のべた病原学的診断法はあくまでも死後また性殺 時に可能な方法で, 豚では生前診断に応用できない.

3.5.2.2 免疫学的診断法: 現症中の豚の生前診断, 抗 図8 色素試験の術式

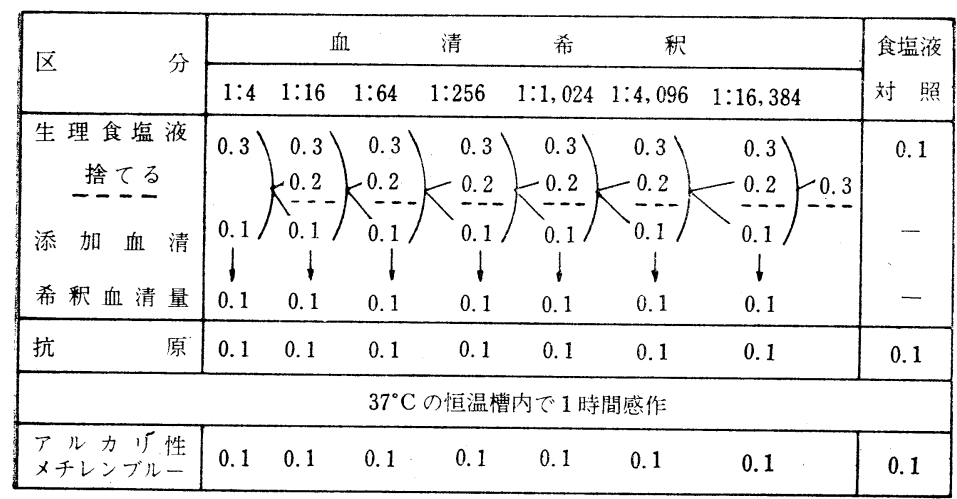

数分後，スライドグラス上に 1 滴とり，カバーグラスでおおい 400 倍で 鏡検する
体調査およびトキソプラズマの污染状況を知るには免疫 学的診断法によらねばならない，その方法には色素試 験, 補体結合反応(阻止反応), 赤血球凝集反応などの血 清反応と皮内反応とがある.

i . 色素試験 (Dye test) : この反応はSABIN \& FELDMAN によって報告され，トキソプラズマの感染によっ て産生された抗体を定量的侸明する方法である。これ は新鮮トキソプラズマ虫体が, アルカリ性メチレン青に 濃染するが，抗体と新鮮健康人血清中に含まれる特殊な 因子 Accessory factor (単化 A F と呼ばれている)の作用 を同時にうける之, 虫体の細胞質に变性が括きて, メチ レン青に染まらなくなるといら現象を応用したすのであ る.

色素試験実施要領(図 8): 被検血清はあらかじめ生理 食塩液で 4 倍に希瀵し， $56^{\circ} \mathrm{C}$ て 3 分間非働化して抢く。 ついで生理食塩液で 4 倍段階希积し，16,384 倍( 7 管) まで行ない各管 $0.1 \mathrm{ml}$ ずつ残るようにする. 対照とし て被検血清と同様に希积した既知陽性血清抒よび生理食

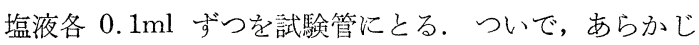
め R H 株を腹腔内に接種しておいた 3 日目のマウスの腹 腔液を生理食塩液ととも注射器でとり，1,500 rpm 5 分間遠沈し, マウス 1 頭分の腹腔液の沈渣を $1 \mathrm{ml}$ の生 理食塩液飞浮遊されたものに $4 \mathrm{ml}$ の $\mathrm{AF}$ を含む人血清

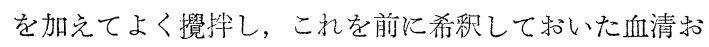
よび対照の各管に $0.1 \mathrm{ml}$ ずつ分注, 攪拌後, 恒温槽内 で $37^{\circ} \mathrm{C} 1$ 時間感作する. 感作後, 取り出し, アルカリ 性メチレン青* $0.1 \mathrm{ml}$ ずつを各管に加兄, 数分数スライ ドグラスの上に 1 滴ずつたらし，カバーグラスをのせ 400 倍の顕微鏡下でメチレン青に染まった虫体と染まら ない虫体の数を計測する。ただし, 細胞内の虫体は除外 する. 判定は染まらない虫が $50 \%$ 以上存在する血清の 最高希釈倍数をその血清の力洒とする.この場合, 生理 食塩液対照において, 染まる虫体が $90 \%$ 以上をしめ,

対照の陽性血清が既定の陽性価を示さ なければならない。豚に括ける陽性限 界は 16 倍を疑陽性, 64倍を陽性とし ている.色素試験は反応が鋭敏で特異 性の高い血清反応であり，また他の血 清反応より早期に抗体を証明すること ができる．豚のトキソプラズマ病にお いては発病後 5 日目頃から抗体の上㫒 が認められ，7〜10 日目に 1,000 倍か ら 16,000 倍に達し，長期間接続する.

*メチレン青のエチールアルコール 飽和液 $1 ：$ pH 11 の緩衝液 $(0.53 \%$ の $\mathrm{Na}_{2} \mathrm{CO}_{3} 9.75 \mathrm{ml}$ と $1.91 \%$ の $\mathrm{Na}_{2}$ $\mathrm{B}_{4} \mathrm{O}_{7} \cdot 10 \mathrm{H}_{2} \mathrm{O} 0.27 \mathrm{ml}$ を混じたもの) 9 の割合に加えたもの. 
したがって現症中の豚の生前䛦断の一助となる.

ii. 補体結合阻止反応 : 豚血清は特殊な処理を行なえ ば直接法も可能であるが，一般的な方法では抗原と結合 する場合に補体結合能がなくなるので阻止反応が用いら れている.陽性抗原としては，10日卵齗の発育鷄卵の奖 尿膜上にマウス由来のトキソプラズマを滴下して感染さ せ, ポックの生じた奨尿膜（付着した卵黄を生理食塩液 で完全に洗い落とす）に奨尿液を加え，ホモブレンダー で乳剤にし, 凍結融解を繰り返すか, 超音波（音波でも よい）で破壊抽出し, 超速遠沈した上清か, または感染 マウスの腹腔液の遠沈沈渣を弥溜水, 涷結融解, または 超音波で破壊したものの遠沈上清を使用する. 正常抗原 としては前者の場合には正常卵の奨尿膜と奨尿液とを混 合したもの, 後者の場合には健康マウスの脾の乳刜を陽 性抗原の場合之同様に処理したものを使用する.

補体結合阻止反応の実施要領 : この反応の発現機序は 補体結合能を有するモルモット色疫血清（指示血清）と トキソプラズマ抗原との間に成立する補体結合反応を豚 血清中の抗体が阻止する現象であり，これを溶血系を加 えて調べるるのである.まず $60^{\circ} \mathrm{C} 20$ 分間非働化した被 検血清を各管 $0.1 \mathrm{ml}$ ずつ残るように倍数希釈し，あら かじめ指示血清を用い， Box titration によって力価を きめて执いた抗原の 2 単位を含む陽性抗原の $0.1 \mathrm{ml}$ を 加元, 攪汼後 $37^{\circ} \mathrm{C} 1$ 時間感作する ( 1 次感作). つつい て 2 単位の指示血清 $0.1 \mathrm{ml}$ と 2 充単位の補体 $0.2 \mathrm{ml}$ を加光，攪挥後， $4{ }^{\circ} \mathrm{C} 18$ 時間感作用する ( 2 次感作). 感作後, 冷室加ら取り出し, $3 \%$ のめ羊感作血球を加 光， $37^{\circ} \mathrm{C} 30$ 分間反応させた後判定する. 判定は溶血度 により 0 ；完全溶血， 1；75\%溶血，2；50\%溶血, 3； $25 \%$ 溶血, 4 ; 完全溶血阻止とする. $50 \%$ 以上の溶血を示 した血清の最高希釈倍数をその力洒とする. トキソプラ ズマの場合, 反応の陽性限界は 8 倍としている.この反 応は現症中の豚の抗体は証明できないが, 発病後, 2 週
目頃から抗体の上昇が認められるので, 抗体調査には十 分使用できる.

iii. 赤血球凝集反応 (JACOBS \& LUNDE 法)

この反応はトキソプラズマ感染マウスの腹腔液由来の 抗原でタンニン酸処理めん羊血球を和执い（抗原感作血 球)。これを被検血清に加えて反応させると，陽性の場 合には抗原感作血球が凝集し, 陰性の場合には凝集しな いといら現象を応用したものである.

タンニン酸処理血球の作製法 : 保存めん羊血球を $\mathrm{pH}$ 7.2 のリン酸緩衝食塩液 (PBS と略す) で 3 回遠沈洗浄 し, 沈殿量の 40 倍量の $\mathrm{pH} 7.2$ の $\mathrm{PBS}$ を加えて 2.5 $\%$ 血球液を作る. この血球液に $\mathrm{pH} 7.2$ の $\mathrm{PBS}$ で希 釈したタンニン酸の 2 万倍溶液（最近では 8 万倍を使用 している）を等量加光, $37^{\circ} \mathrm{C} 15$ 分間加温後 $\mathrm{pH} 7.2$ の PBS で 1 回遠沈洗浄し, 沈渣に生理食塩液を加えて 2.5 \%の血球液を作る. その一部を本試験のタンニン酸処理 血球液対照に使用し, 他の一部は抗原処理血球の作製の ために使用する。

抗原処理血球の作成： pH 6.4 の PBS を4, 生理食 塩液で使用濃度 (あらかじめ Box titration によってき めた濃度)に希积した抗原 1 , タンニン酸処理血球を 1 の割合に上記の順に混合し, 室温で 15 分間感作し，そ の後 $1 \%$ NRS* で 2 回遠沈洗浄後， $2 \%$ NRS でもと の血球液量 (2.5\%) にしたものを抗原感作血球として 使用する. 対照に使用するタンニン酸処理血球は抗原を 加えずに生理食塩液（抗原のかわり）と $\mathrm{pH} 6.4$ のPBS とを加党，抗原感作血球の場合と同様の処理を行なった ものである.

* NRS : $56^{\circ} \mathrm{C} 30$ 分間非働化した健康家東血清を所要 の割合にpH 7.2 PBS に加えたもの，信藤らは家秉血 清のかわりに健康豚血清を $3 \%$ になるょらに PBS に加 え( $3 \%$ NSS) boilling して使用することを推奨してい る.

図 9 赤血球凝集反応の術式

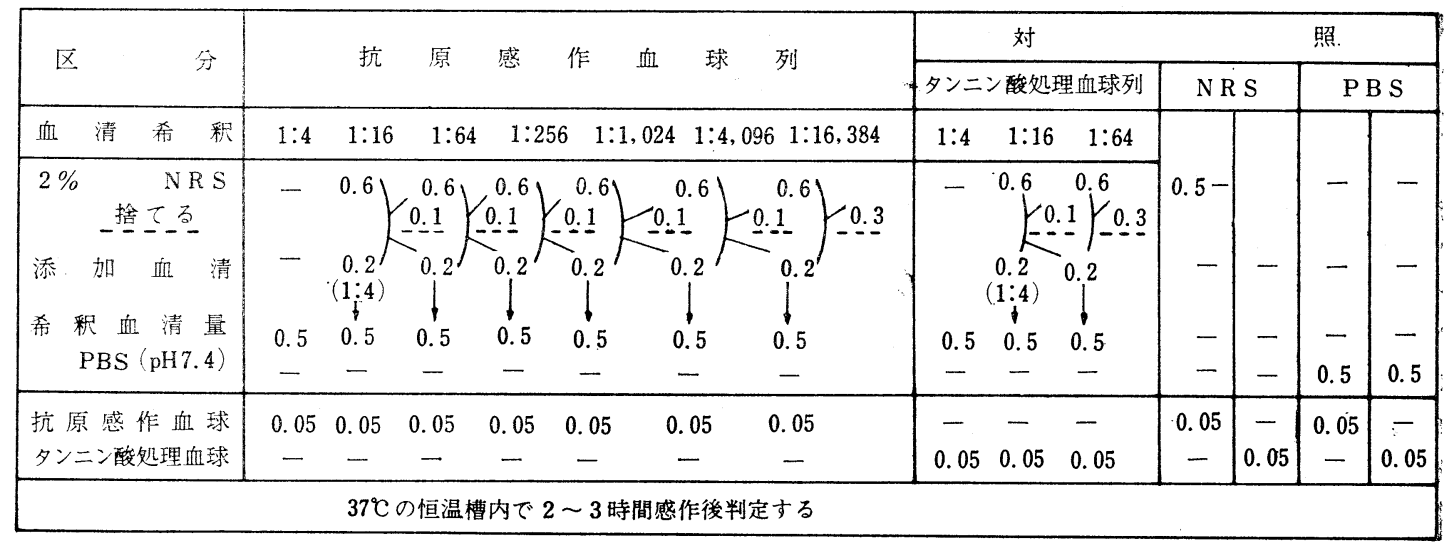

NRS : 健康家鬼血清 PBS：リ认酸緩衝食塩液 
抗原の作製法: 感染マウス腹腔液を生理食塩液で採集 乙, $2,500 \mathrm{rpm} 15$ 分間遠沈後, 沈渣重量の 10 倍量の滅 菌蒸溜水学加光, 十分攪拌して $4^{\circ} \mathrm{C} て ゙ 1$ 夜抽出する。抽 出後 $10,000 \mathrm{rpm} 1$ 時間冷凍遠沈し, 遠沈上清に同量の $1.7 \%$ 食塩液を加光て食塩濃度を $0.85 \%$ 亿修正し，小 試験管に小分㜾して使用時まで $-20^{\circ} \mathrm{C}$ 以下に保存する か，また以凍結乾燥して保存して招く。この抗原は補体 結合反応 (阻止反応) 打上び皮内反応飞も使用できる.

赤血球凝集反応の実施要領：吕かでめ被検血清, 対 照用の既知陽性血清招上び陰性血清の原液 $0.5 \mathrm{ml}$ を2 $\%$ NRS で 4 倍飞希釈し, $56^{\circ} \mathrm{C} 30$ 分間非働化後, 等量の洗 浄沈殿血球を加兄て $4^{\circ} \mathrm{C} て ゙ 1$ 夜非特異㠜集素を吸収した ものを $2 \%$ NRSで 4 倍段階希釈して図 2 亿示した要領 で反応を行なう。判定は管底に沈下した血球の程度にし たがって，そのパターンを+1から+4亲でに分けて判 読し十 2 走示した血清の最高希积倍数をとの血清の力洒

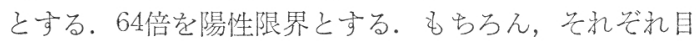
的のためにたてられた刘照のすべてが満足するようなパ ターンを示さなげればならない。この反応は補体結合阻 止反応とほ汴同時期に陽転するので現症中の豚の生前䛦 断には応用できないが，抗体調査には十分使用できる。

\section{iv. 皮内反応}

トキソプラズマ感染化よる特異的なアレルギー性局所 反応を調べる方法で岁る。抗原市市販さ机ているが作製 法以赤血球凝集反応抗原之同様で, 凍結乾燥して保存す る.

皮内反応の実施要領: 凍結乾燥抗原に所定量の溶解液 家加光て完全にとかし，2段針をつけたツベルクリン用 注射器で, 豚の耳翼の中央部の皮内に正確に $0.2 \mathrm{ml}$ 注射する. 判定は48時間後, 注射部位に現われる発赤, 腫脹をともなら皮膚反応の直径を計測し, $15 \mathrm{~mm}$ 以上 のものを陽性, $10 \mathrm{~mm}$ 14 mm のものを疑陽性, $9 \mathrm{~mm}$ 以下を陰性とする。皮内反応は血清反応上りかなり秥く 孔て陽転する. この反応は生後 $2 \sim 3$ 力月の豚では色素 試験との一致率は低く, 高年龄になるに従って一致率が 高くなる傾向がある。それで, 固体についての検査に使 用するよりも，む乙ろ地域的なトキソプラズマの污染状 沉它調べるのに能率的な方法である。

3.5.2.3 病理学的診断: 急性の症状を現わして死亡し たもの, をた㳊殺したものを解剖すると, 胸水, 腹水の 增量がみられ, 最も著しい変化流両側の肺の退縮不全

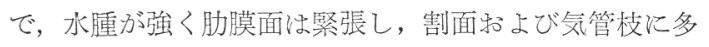
量の渗出液が認められる。リンパ節は腫脹し, 辺縁执上 び実質内にびょえ性の出血がみられ, また壊死集が認め られる.とくに肝門, 胃門, 肺, 腸間膜のリンパ節汇注 意を要する. その他, 脾の腫大, 沪胞㐨よざ脾材の不明

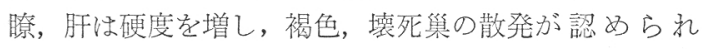
๖.

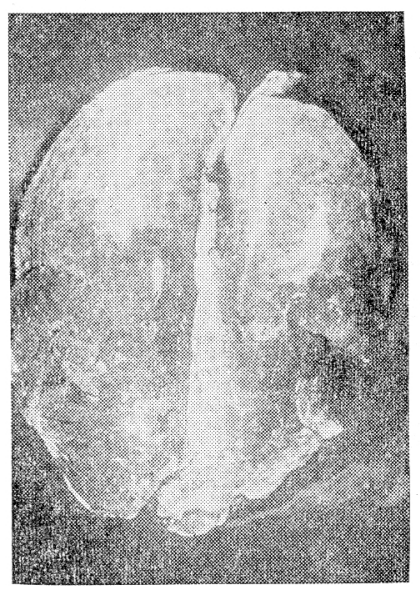

写真12 雨肺水腫が強く, 肋膜面が緊張する。.

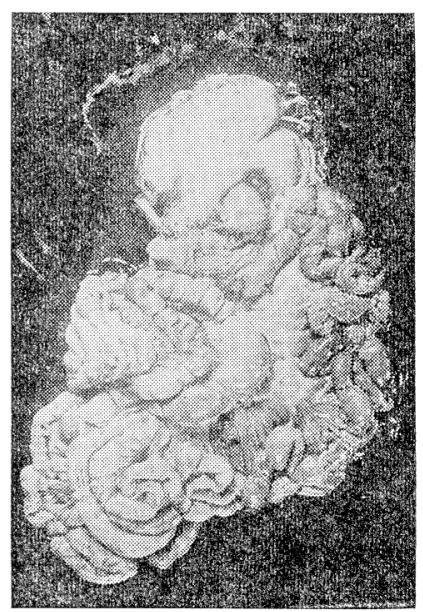

写真13 リンパ節の著しい腫脤

\subsubsection{4 総合診断}

トキソプラズマ病は豚コレラのように急激に広がり, 豚の年龄に関倸なく短期間に全隇するようなことはな い。しかし, 豚コレラの予防注射に関係なく, 子豚和よ び中豚は一年中散発的に発症する。臨床症状は豚コレラ と非常によく似て抢り，漂とんど区別することがでさな い。ただ，トキソプラズマ病の場合には後躬麻痺がな く, 著明な肺焱症状 (呼吸困難) が認められる。解剖所 見で浪雨側の肺の很縮不全, 水腫拉よびリンパ節の出血 腫張等がみられ，これらの叙抹標本を作製して鏡検すれ ば原虫を磪認することができる。しかし，生前に抗原虫 剂を使用した場合, 塗抹標本で原虫を確認与ることが困 難なので, 原虫分離を行なら。きた死亡打よび屠殺前に 採血して持けば色素試験が併用できるので晾断が正確か つすみやが行ならことができる。現症中の豚の生前診 断は色素試験淿限る。 
地方会だより

\subsection{3 予防・治療}

現在，有効なワクチンがないので，ワクチン注射によ る䂆防はできない，広い意味の予防法としては污染して いる養㟲場から子豚を購入しないようにすること，常に 豚をよく観察し，元気のないようなものは直ちに体温を 測り, 発熱している場合は隔離し, 十分消毒 (1\%ク口 ールクレン゙ール) して, 他の健康豚に感染しないように 注意する，隔離した豚の症状が悪化するような場合は直 ちに病性鑑定材料とし, 速やか飞病名を決定して, 病気 飞対する正しい処置をすみやかに実施した湾うがよい。 死亡括よび屠殺豚の処理は豚コレラの場合に準じて行な う.

現在, トキソプラズマ病の治療隹としてピリメサミン 特よびサルファ剂が有効であり，サルファ剤のなかでは サルファモノメトキシン, サルファジメトキシンが最も 有効である，角田らは実験的にトキソプラズマを豚に感
染させ，いろいろの時期飞治療（ピリメサミン拈よび前 述した 2 つのサルファ剤の単味または混剤を 1 週間連 用）を試みている，その結果，感染後 1 週目まで薬剤 を投与した場合には臨床的にも極めて有効であり，また 体内の原虫を完全に駆逐することができた。乙かし，感 染後 2 週以上経過した豚に薬剂を投与した場合には臨床 的には非常に有効でめったが，殺後全頭から原虫が証明 されている.また野外豚では発熱と同時特よび軽重さま ざまの症状を現わしたるのについて試験を行なっている が，臨床的には非常に効果があったが，潘とんどすべて の豚から原虫が分離されている．乙たがってこれらの薬 剤は PAS 反応陰性の増殖型の原虫にはきわめて強い殺 虫効果を有するが， PAS 反応陽性のシスト怙よび遊離 虫体にはほとんど効果がないようである。そ机で重い症 状を現わしている病豚は飼料効率も悪く，また感染源に なるのですみやかに殺処分するのがよい（鉿木 恭）

\section{地方会だより}

\section{小動物 講 習 会 \\ 九州地区 (大分県獣医師会)}

1. 開催期日 昭和 46 年 8 月 1 日（日） $10.00 \sim 17.00$

2. 開催場所 別府市北浜 2-9 別府国際観光会館

[電話＼cjkstart別府 (3)-1111（代表）]

3. 講 師 佐藤 敬氏 (日本大学農獣医学部)

高橋 貢氏 (麻布獣医科大学)
4. 講習課目

（1） 小動物の全身麻酔飞ついて（10.00１4.00）

(2) レントゲンによる診断について(14.00〜17.00)

\section{公 衆 衛生 講 習会} 九州地区 (宮崎県獣医師会)

九州ブロックの公衆衛生講習会が宮崎県獣医師会担当 （田尻易会長）飞より, 宮崎県で 8 月 20 日 (金) 開催 される。

\section{会}

太昭和 46 年度農業共済団体指定獣医師等講習会開催計画

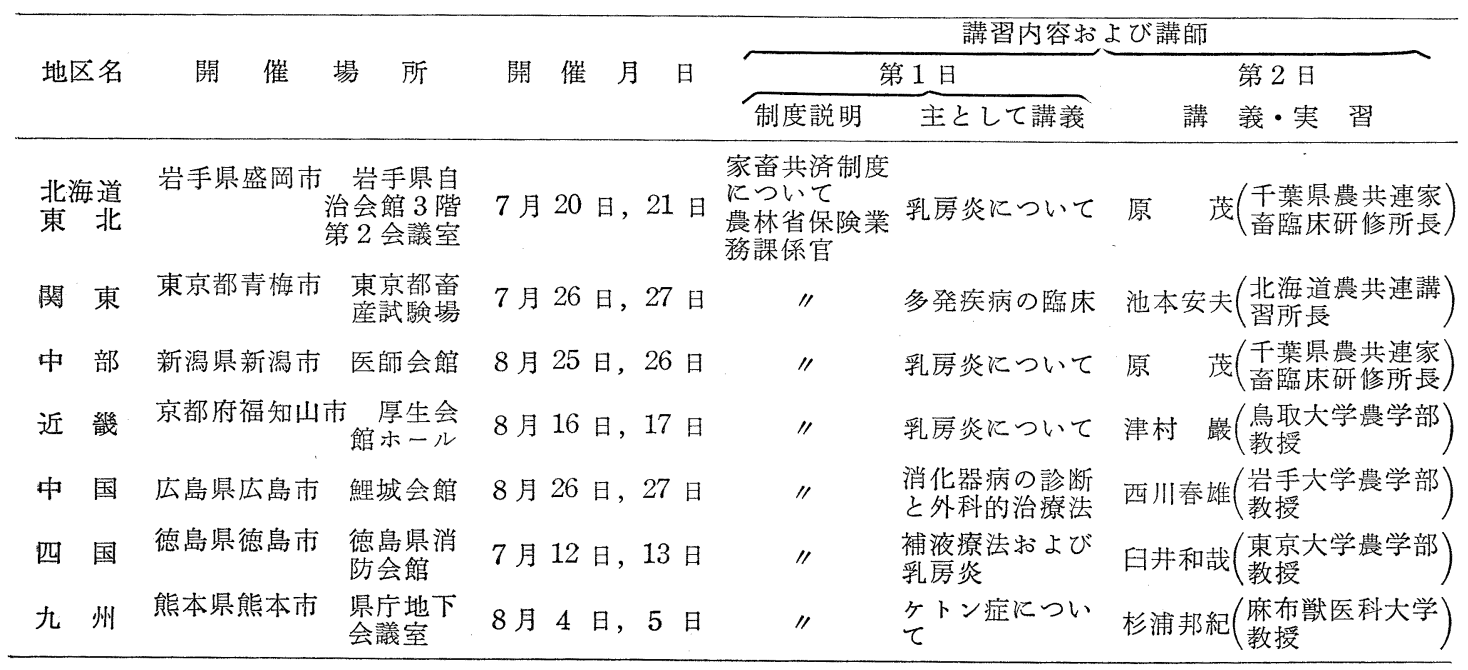

日獣会誌 $24 \quad 391 \sim 399$ (1971) 391 